Article

\title{
Role of Phase Change Materials Containing Carbonized Rice husks on the Roof-Surface and Indoor Temperatures for Cool Roof System Application
}

\author{
Hong Gun Kim ${ }^{1}$, Yong-Sun Kim ${ }^{1}$, Lee Ku Kwac ${ }^{1}$, Mira Park ${ }^{2, *}$ and Hye Kyoung Shin ${ }^{1}$ **D \\ 1 Institute of Carbon Technology, Jeonju University, 303 Cheonjam-ro, Wansan-gu, Jeonju-si, \\ Jeollabuk-do 55069, Korea; hgkim@jj.ac.kr (H.G.K.); wva223g6@naver.com (Y.-S.K.); \\ kwac29@jj.ac.kr (L.K.K.) \\ 2 Carbon Composite Energy Nanomaterials Research Center, Woosuk University, Wanju, \\ Chonbuk 55338, Korea \\ * Correspondence: wonderfulmira@woosuk.ac.kr (M.P.); jokwanwoo@jj.ac.kr (H.K.S.); \\ Fax: +82-63-270-3105 (M.P.); +82-63-220-3161 (H.K.S.)
}

Academic Editor: Ana Ines Fernandez Renna

Received: 30 June 2020; Accepted: 17 July 2020; Published: 19 July 2020

check for updates

\begin{abstract}
This study researches the effect of phase change materials (PCMs) containing carbonized rice husks (CRHs) in wood plastic composites (WPCs) as roof finishing materials on roof-surface and indoor temperatures. A cool roof miniature model was prepared, and measurements were taken using three fixed temperatures of 30 to $32^{\circ} \mathrm{C}, 35$ to $37^{\circ} \mathrm{C}$, and 40 to $42^{\circ} \mathrm{C}$. Sodium sulfate decahydrate $\left(\mathrm{Na}_{2} \mathrm{SO}_{4} \cdot 10 \mathrm{H}_{2} \mathrm{O}\right)$ and paraffin wax were selected as the PCMs. CRHs were used as additives to improve the thermal conductivities of the PCMs. At lower fixed temperatures such as 30 to $32{ }^{\circ} \mathrm{C}$ and 35 to $37^{\circ} \mathrm{C}$, the rates of increase of the surface temperatures of roofs containing CRHs with $\mathrm{Na}_{2} \mathrm{SO}_{4} \cdot 10 \mathrm{H}_{2} \mathrm{O}$, and paraffin wax, were observed to gradually decrease compared to those of the roofs without PCMs. The indoor temperatures for the above-mentioned PCMs containing CRHs were maintained to be lower than those of the indoors without PCMs. Additionally, as the CRH content in the PCM increased, the rates of increase of the roof-surface and indoor temperatures decreased due to a faster roof heat absorption by PCMs through the improved thermal conductivity of CRHs. However, under higher artificial temperatures such as 40 to $42{ }^{\circ} \mathrm{C}, \mathrm{Na}_{2} \mathrm{SO}_{4} \cdot 10 \mathrm{H}_{2} \mathrm{O}$ with $\mathrm{CRHs}$ exhibited no effect due to being out of latent heat range of $\mathrm{Na}_{2} \mathrm{SO}_{4} \cdot \mathrm{H}_{2} \mathrm{O}$. For paraffin wax, as $\mathrm{CRH}$ content increased, their roof- surface and indoor temperatures decreased. Especially, the surface temperature of the roof containing paraffin contained $5 \mathrm{wt}$. \% CRHs reduced by $11{ }^{\circ} \mathrm{C}$, and its indoor temperature dropped to $26.4^{\circ} \mathrm{C}$. The thermal conductivity of PCM was enhanced by the addition of CRHs. A suitable PCM selection in each location can result in the reduction of the roof-surface and indoor temperatures.
\end{abstract}

Keywords: phase change materials; carbonized rice husk; cool roof system; thermal conductivity

\section{Introduction}

Direct exposure of construction surfaces to sunlight has been observed to increase the temperature in buildings; this is because of the higher heat storage and lower heat emission of materials such as concrete or metal deck [1-6]. This can lead to an urban heat island phenomenon that causes the central city area temperature to be higher than that of suburban areas, thus contributing to global warming [7-10]. Therefore, employing cool roof systems using phase change materials (PCMs) as building insulation is required. These minimize the heat transfer by limiting it to the interior of 
building, and can also maintain a stable indoor temperature, while providing the highest energy saving for electricity consumption [11-15] (see in Figure 1).

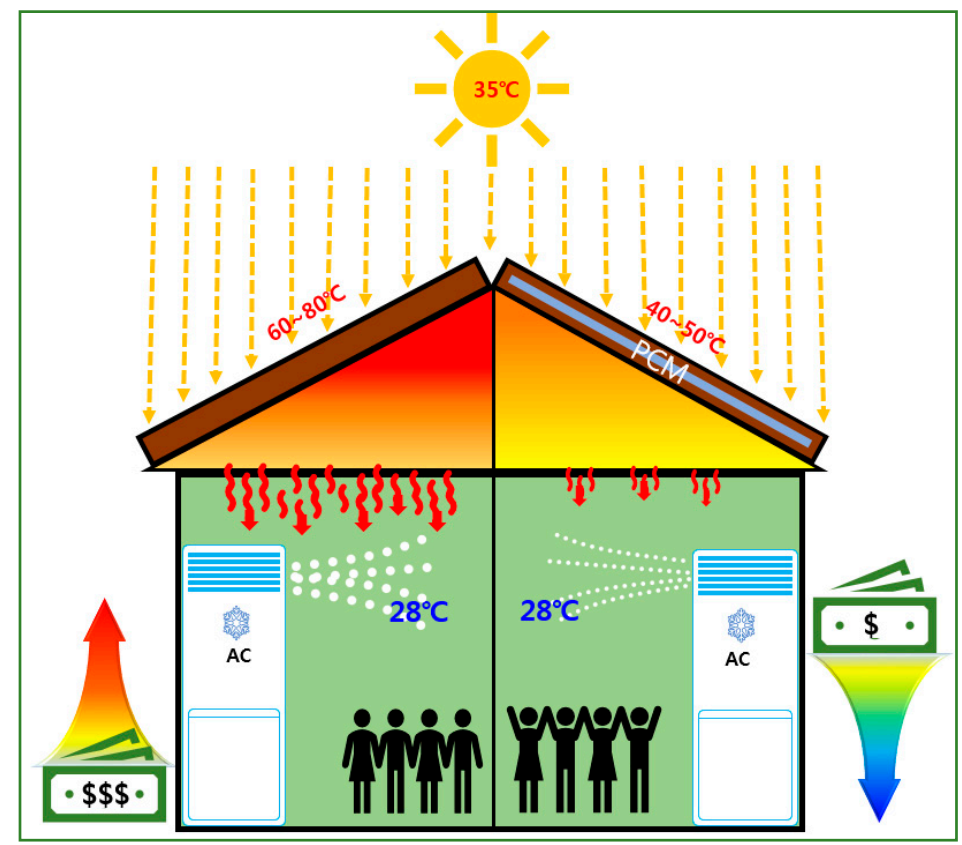

Figure 1. Schematics for the effect of cool roof system using phase change materials (PCM) on energy consumption saving.

PCMs used for cool roof system applications are materials capable of absorbing or releasing thermal energy in the form of latent heat during the solid-liquid transition, and are extensively applied in many energy economy areas due to sustained heat source temperature, high energy density, and repeated utilization [16-20]. Therefore, by utilizing the advantages of PCMs, numerous researchers have studied the effect of only using PCMs on roof-surface and indoor-temperature reduction for cool roof systems. Yang et al. [21], Dong et al. [22], and Jayalath et al. [23] researched cool roof systems using PCM without the additives. Regarding the results, PCM roof temperatures were reduced or heat transfer was delayed. Saffari et al. [24] reviewed papers on the numerical simulation of buildings with PCMs for passive cooling using whole building energy simulation tools. Costanzo el al. [25] investigated commercial PCMs employed as mats within drywall partition systems in air-conditioned lightweight office buildings under thermostatic control, and their influence on the indoor operating temperatures and cooling load.

Nevertheless, PCMs have major disadvantages such as supercooling and phase segregation due to low thermal conductivity, corrosion, and latent heat loss during liquid-solid repetition. Therefore, to inhibit these disadvantages, various additives have to be added to PCMs. Carbonized materials are widely used to improve the thermal conductivity, which results in the prevention of supercooling and phase segregation. Additionally, they possess favorable properties such as noncorrosion by contact with PCMs, chemical stability, nontoxicity, and being lightweight [26-36]. Amongst the carbon materials with these advantages, carbonized rice husks (CRHs) are inexpensive as they are waste materials that can be easily obtained. Additionally, the convex shape of rice husks can maximize the energy storage capability by a simple impregnation method and increase the specific area for heat transfer in PCMs.

The aim of this study was to research the attainment of reduced roof-surface and indoor temperatures through fast roof heat absorption by improving the thermal conductivity of PCMs through the addition of CRHs. In addition, the study aimed to minimize the energy loss in latent heat storage and retrieval progress by removing the phase segregation that is not completely soluble 
during melting and the supercooling problems that remain molten PCMs during crystallization to ensure timely release of the heat of fusion. To apply the cool roof system, a cool roof miniature model was prepared.

\section{Experimental}

\subsection{Materials}

Rice husks were purchased from SAMWHA RICE MILL Co. in Korea. PCMs were used as received; $\mathrm{Na}_{2} \mathrm{SO}_{4} \cdot 10 \mathrm{H}_{2} \mathrm{O}$ (phase change temperature of $32.4{ }^{\circ} \mathrm{C}$ with a purity greater than $98.0 \%$ ) was received from DAEJUNG Co. (Siheung-si, Gyeonggi-do, Korea), and Paraffin wax (phase change temperature of $48^{\circ} \mathrm{C}$, medical grade) was supplied from WR Medical Electronics Co. (Maplewood, MN, USA). Wood plastic composite (WPC) structure samples were obtained from YES WOOD Co. in Korea.

\subsection{Preparation of $\mathrm{CRHs}$}

The CRHs were carbonized for $1 \mathrm{~h}$ at a temperature of $1000{ }^{\circ} \mathrm{C}$ in muffle furnace under an atmosphere of $\mathrm{N}_{2}(99.999 \%)$ without a stabilization procedure. The obtained CRHs were used as additives to improve the thermal conductivity of PCMs.

\subsection{Preparation of PCM/CRH Packs and Set Up of Cool Roof Miniature Model}

PCM/CRHs (100 g) packs were prepared by physically mixing the PCM powders evenly with 0,1 , 3,5 wt. \% CRHs, respectively, and then inserting the mixture in polyethylene (PE) bags. Hot pressing the ends of the PE bag enclosed the bags. The end of PE bag containing PCM/CRH were closed using a hot press. Table 1 shows the density of $\mathrm{Na}_{2} \mathrm{SO}_{4} \cdot 10 \mathrm{H}_{2} \mathrm{O} / \mathrm{CRH}$ and paraffin wax/CRHs in PE bags. The density increased with the increase of CRHs. Figure 2a,b exhibits the photographs of raw rice husks and corresponding $\mathrm{CRH}$ that were prepared via carbonization at $1000{ }^{\circ} \mathrm{C}$ without a stabilization procedure. The photographs demonstrate that the CRHs experienced a reduction in size due to thermal decomposition while maintaining the convex shape of raw rice husks. The convex shape of CRHs improves their impregnation into the molten PCM, and therefore reduces the latent heat loss by the additives. In addition, the high aspect ratio of the CRHs may also increase the specific area of heat transfer by reducing the distances between CRHs within the PCM. Figure 2c,d show optical microscopy images of the $\mathrm{Na}_{2} \mathrm{SO}_{4} \cdot 10 \mathrm{H}_{2} \mathrm{O} / \mathrm{CRH}$ and paraffin wax/CRHs obtained during cooling from the melt in the PE bags. It can be observed that the CRHs were impregnated within the $\mathrm{Na}_{2} \mathrm{SO}_{4} \cdot 10 \mathrm{H}_{2} \mathrm{O}$ and paraffin wax were uniformly dispersed. Figure 3 depicts the cool roof miniature model. The test measured the upper surface of WPC, as well as the indoor temperatures, using a fixed heat source (at 30 to $32{ }^{\circ} \mathrm{C}, 35$ to $37^{\circ} \mathrm{C}$, and 40 to $42{ }^{\circ} \mathrm{C}$ ). The fixed heat source was controlled through temperature variation ( 30 to $32{ }^{\circ} \mathrm{C}: 725 \mathrm{~W}, 35$ to $37^{\circ} \mathrm{C}: 855 \mathrm{~W}$, and 40 to $42{ }^{\circ} \mathrm{C}: 1000 \mathrm{~W}$ ) by the encoder of a halogen lamp (GEO-MH 1000W (A) B/T, GEO LIGHTING, Anseong, Korea). The temperature variation of the thermocouple was measured through a temperature readout box. The obtained data were automatically recorded and saved on a computer.

Table 1. Density of $\mathrm{Na}_{2} \mathrm{SO}_{4} \cdot 10 \mathrm{H}_{2} \mathrm{O} / \mathrm{CRH}$ and paraffin wax/carbonized rice husks (CRHs).

\begin{tabular}{ccccc}
\hline PCM & \multicolumn{4}{c}{ PCM:CRH wt. $\%$} \\
\hline $\mathrm{Na}_{2} \mathrm{SO}_{4} \cdot 10 \mathrm{H}_{2} \mathrm{O}: \mathrm{CRHs}$ & $100: 0$ & $99: 1$ & $97: 3$ & $95: 5$ \\
Density $\left(\mathrm{kg} \mathrm{m}^{-3}\right)$ & $858.88 \pm 15.6$ & $867.55 \pm 3.3$ & $883.00 \pm 7.0$ & $894.80 \pm 4.2$ \\
Paraffin wax:CRHs & $100: 0$ & $99: 1$ & $97: 3$ & $95: 5$ \\
Density $\left(\mathrm{kg} \mathrm{m}^{-3}\right)$ & $450.12 \pm 8.4$ & $477.07 \pm 6.2$ & $501.56 \pm 6.9$ & $521.25 \pm 9.3$ \\
\hline
\end{tabular}




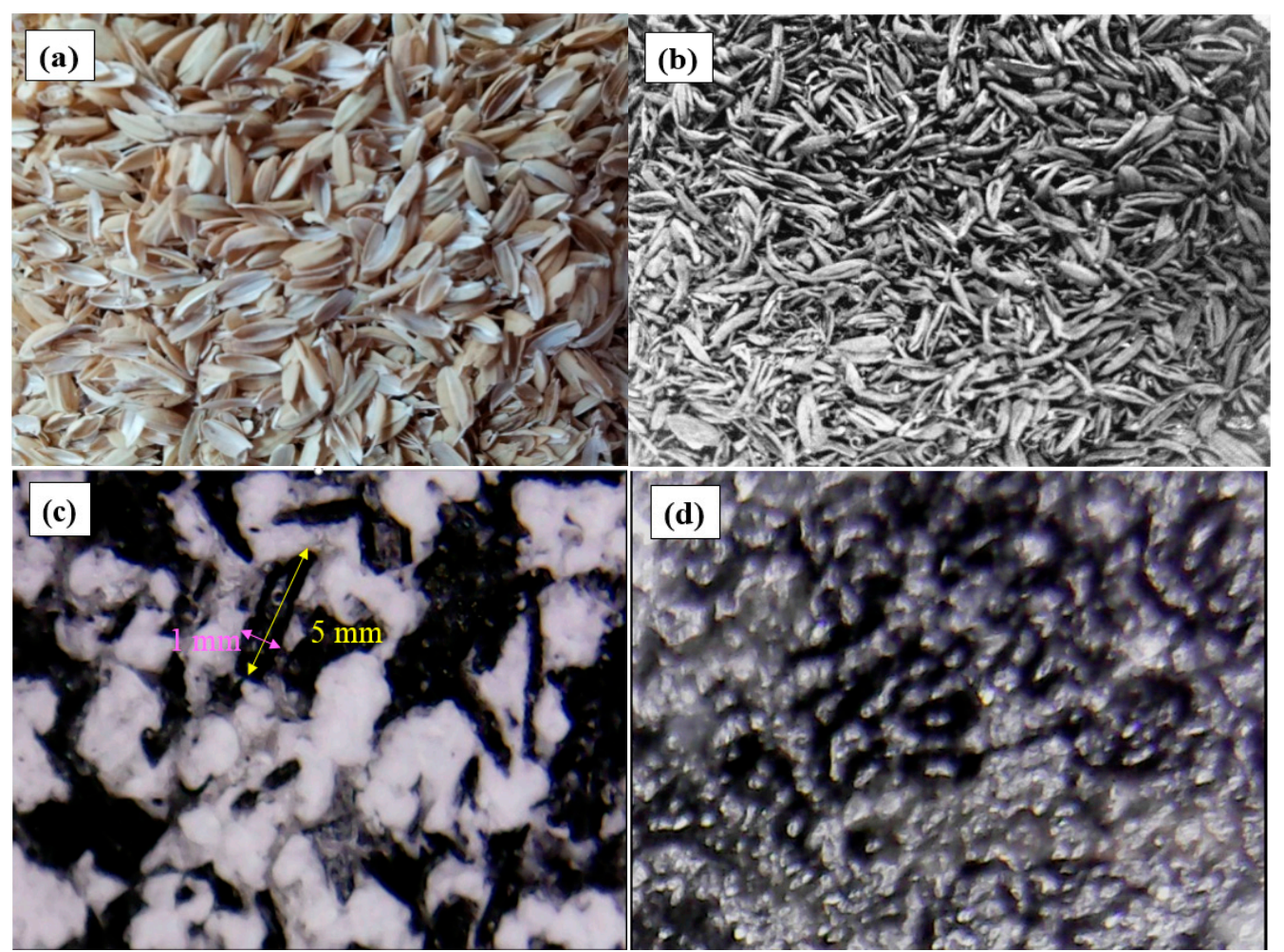

Figure 2. Photographs of (a) raw rice husks and (b) CRHs. Optical microscopy images of (c) $\mathrm{Na}_{2} \mathrm{SO}_{4} \cdot 10 \mathrm{H}_{2} \mathrm{O} / \mathrm{CRH}$ and (d) paraffin wax/CRHs (magnification: $200 \times$ ).

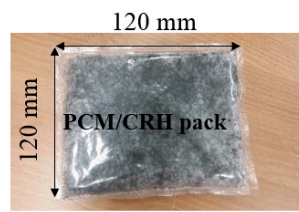

(a)

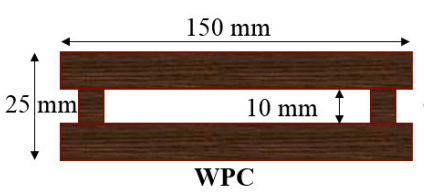

(b)

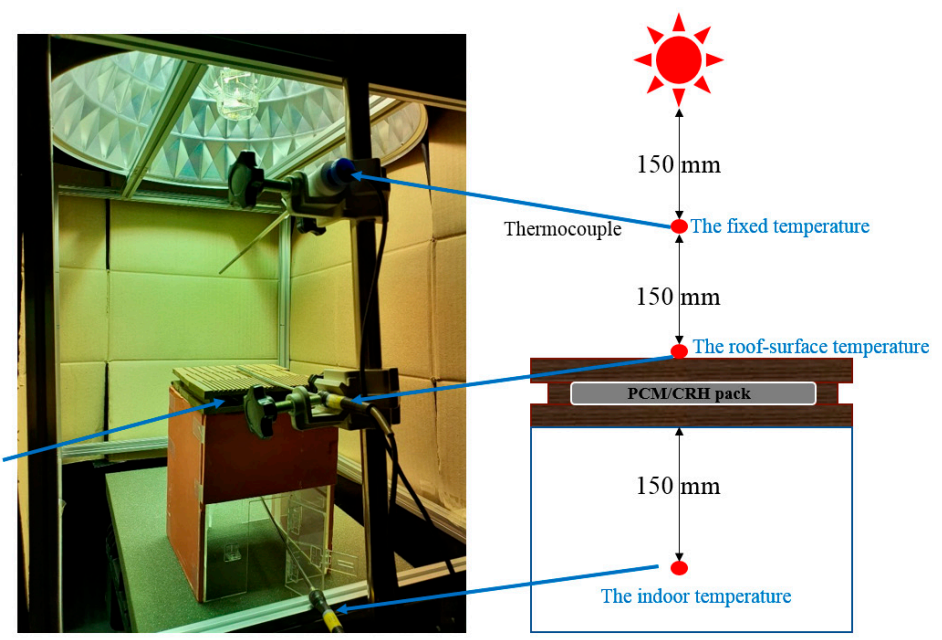

(c)

Figure 3. Set up of cool roof miniature model; (a) photo of phase change materials (PCM)/CRH pack; (b) schematic diagram for cross-section for the wood plastic composite (WPC) cross-section; and (c) thermocouple location for temperature measurement.

\subsection{Characterization}

X-ray diffraction (XRD) pattern was recorded by a RIGAKU, D/MAX-2500 instrument (Rigaku Corporation, Tokyo, Japan) with CuK $\alpha$ radiation generated at $40 \mathrm{kV}$ and $30 \mathrm{~mA}$ at a scan rate of $0.4 \% \mathrm{~min}$. The thermal conductivity was measured using a TPS2500S instrument (Hot Disk, Göteborg, Sweden); the data was acquired using a sensor sandwiched between two identical PCM/CRH composites. The PCM/CRHs composites used for the thermal conductivity measurements were obtained through a melting method. The PCMs were melted at their respective phase change temperatures followed by the addition of $0,1,3,5 \mathrm{wt}$. \% CRHs. The resulting mixtures were placed in a cuboid shape 
bowls $\left(13 \times 13 \times 2 \mathrm{~cm}^{3}\right)$ and cooled at room temperature to yield PCM/CRH composites that were used to measure the thermal conductivity. The latent heat of the PCM/CRHs was measured using differential scanning calorimetry (DSC 25, TA instruments Inc., DE, USA) at a heating and cooling rate of $1{ }^{\circ} \mathrm{C} \mathrm{min}-1$ in a nitrogen atmosphere. The samples were prepared by cooling at room temperature after mixing the melted PCM with 0, 1, 3, $5 \mathrm{wt}$. \% CRHs. Approximately $10 \mathrm{mg}$ of the samples was used for the DSC analysis. Estimation was performed based on the respective endothermic areas of the DSC curves during PCM melting with TA Instruments TRIOS v4.4.0 software package.

\section{Results and Discussion}

\subsection{XRD and Thermal Conductivity of PCM/CRHs}

Figure 4 depicts the XRD patterns of rice husks and CRHs. As shown in Figure 4a, rice husk has characteristic peaks at $2 \theta=13.5^{\circ}, 17^{\circ}, 22^{\circ}$, and $35^{\circ}$, corresponding to the (110), (11̄0), (200), and (040) planes with crystalline regions, such as cellulose, and with a broad amorphous region, such as lignin or hemicelluloses. After carbonization, as depicted in Figure $4 \mathrm{~b}$, the CRH diffraction peaks were detected at $2 \theta=26^{\circ}$ and $43^{\circ}$, which are associated with the (002) and (100) planes. The (002) peak results from the graphitization conversion, and thus demonstrated the successful carbonization of the rice husks. Table 2 shows the thermal conductivities of PCM/CRHs. The thermal conductivities of $\mathrm{Na}_{2} \mathrm{SO}_{4} \cdot 10 \mathrm{H}_{2} \mathrm{O}$ and paraffin wax increased with increased CRH content due to the higher contact and more dense per-unit area of CRHs, and the thermal conductivities of pure $\mathrm{Na}_{2} \mathrm{SO}_{4} \cdot 10 \mathrm{H}_{2} \mathrm{O}$ were higher than those of pure paraffin wax. Therefore, thermal conductivities of $\mathrm{Na}_{2} \mathrm{SO}_{4} \cdot 10 \mathrm{H}_{2} \mathrm{O} / \mathrm{CRH}$ are generally higher than those of paraffin wax/CRHs under similar conditions.
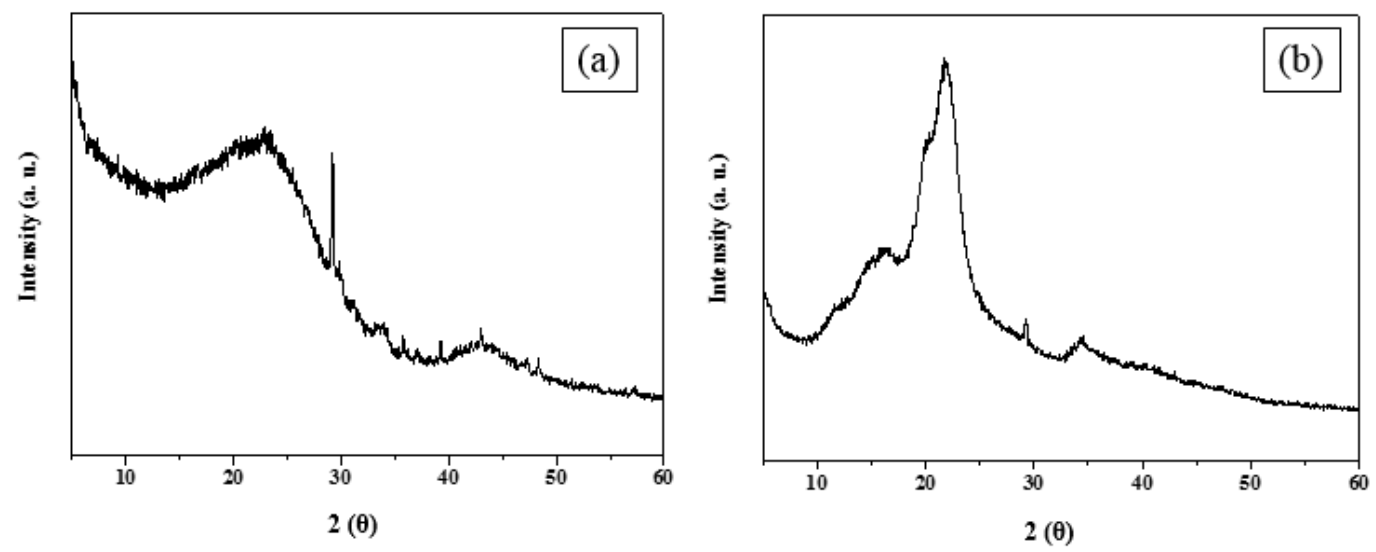

Figure 4. X-ray diffraction (XRD) patterns of (a) raw rice husks and (b) CRHs.

Table 2. Thermal conductivity of PCM/CRHs.

\begin{tabular}{ccccc}
\hline PCM & \multicolumn{4}{c}{ PCM:CRH wt. \% } \\
\hline $\mathrm{Na}_{2} \mathrm{SO}_{4} \cdot 10 \mathrm{H}_{2} \mathrm{O}: \mathrm{CRHs}$ & $100: 0$ & $99: 1$ & $97: 3$ & $95: 5$ \\
Thermal conductivity $\left(\mathrm{W} \mathrm{mK}{ }^{-1}\right)$ & $0.718 \pm 0.007$ & $0.826 \pm 0.008$ & $1.01 \pm 0.007$ & $1.43 \pm 0.004$ \\
Paraffin wax:CRHs & $100: 0$ & $99: 1$ & $97: 3$ & $95: 5$ \\
Thermal conductivity $\left(\mathrm{W} \mathrm{mK}{ }^{-1}\right)$ & $0.14 \pm 0.013$ & $0.22 \pm 0.012$ & $0.34 \pm 0.009$ & $0.40 \pm 0.009$ \\
\hline
\end{tabular}

\subsection{Latent Heat of PCM/CRHs}

Figure 5 depicts the DSC analysis results that quantify the changes in the latent heat value of the PCM according to the CRH content, and its results are summarized in Table 3. The latent heat values of pure $\mathrm{Na}_{2} \mathrm{SO}_{4} \cdot 10 \mathrm{H}_{2} \mathrm{O}$ was $216.13 \pm 2.70 \mathrm{~kJ} \mathrm{~kg}^{-1}$ at the melting temperature of $\mathrm{T}_{\mathrm{m}}$ of $32.4{ }^{\circ} \mathrm{C}$, and paraffin wax was $220.45 \pm 1.62 \mathrm{~kJ} \mathrm{~kg}^{-1}$ at $\mathrm{T}_{\mathrm{m}}$ of $48^{\circ} \mathrm{C}$. Generally, PCMs presented one endothermic peak at melting temperature; however, in the case of paraffin wax, double endothermic 
peaks were observed. The first peak represents the solid-solid conversion, which indicates the change of the ordered phase into the disordered phase, and the second peak, which is the main peak, indicates the solid-liquid conversion. Therefore, in Figure $4 a, b$, the latent heat range of paraffin wax $\left(17 \sim 56{ }^{\circ} \mathrm{C}\right)$ is wider than that of $\mathrm{Na}_{2} \mathrm{SO}_{4} \cdot 10 \mathrm{H}_{2} \mathrm{O}\left(27 \sim 41.5^{\circ} \mathrm{C}\right)$. The latent heat values of $\mathrm{PCMs}$ gradually decreased as the CRH content was increased in Figure $4 \mathrm{a}, \mathrm{b}$ and Table 3. During cooling, the solidifying temperatures of $\mathrm{Na}_{2} \mathrm{SO}_{4} \cdot 10 \mathrm{H}_{2} \mathrm{O}$ and paraffin wax increased with an increase of CRHs. In Figure $5 \mathrm{a}$, the exothermic peak for pure $\mathrm{Na}_{2} \mathrm{SO}_{4} \cdot 10 \mathrm{H}_{2} \mathrm{O}$ was observed at approximately $0{ }^{\circ} \mathrm{C}$; however, $\mathrm{Na}_{2} \mathrm{SO}_{4} \cdot 10 \mathrm{H}_{2} \mathrm{O}$-containing $\mathrm{CRH}$ crystalized at a higher temperature of approximately $10^{\circ} \mathrm{C}$. This is because the thermal conductivity of $\mathrm{Na}_{2} \mathrm{SO}_{4} \cdot 10 \mathrm{H}_{2} \mathrm{O}$ is more improved with the increase of CRHs. In addition, as shown in Figure $4 b$, pure paraffin wax and paraffin wax/CRHs crystallized near the $\mathrm{T}_{\mathrm{m}}$ and at a slightly higher temperature with an increase in CRHs. These results indicate that the addition of CRHs, especially in the case of $\mathrm{Na}_{2} \mathrm{SO}_{4} \cdot 10 \mathrm{H}_{2} \mathrm{O}$, might prevent the supercooling and phase segregation difficulties by improving the thermal conductivity of PCMs.
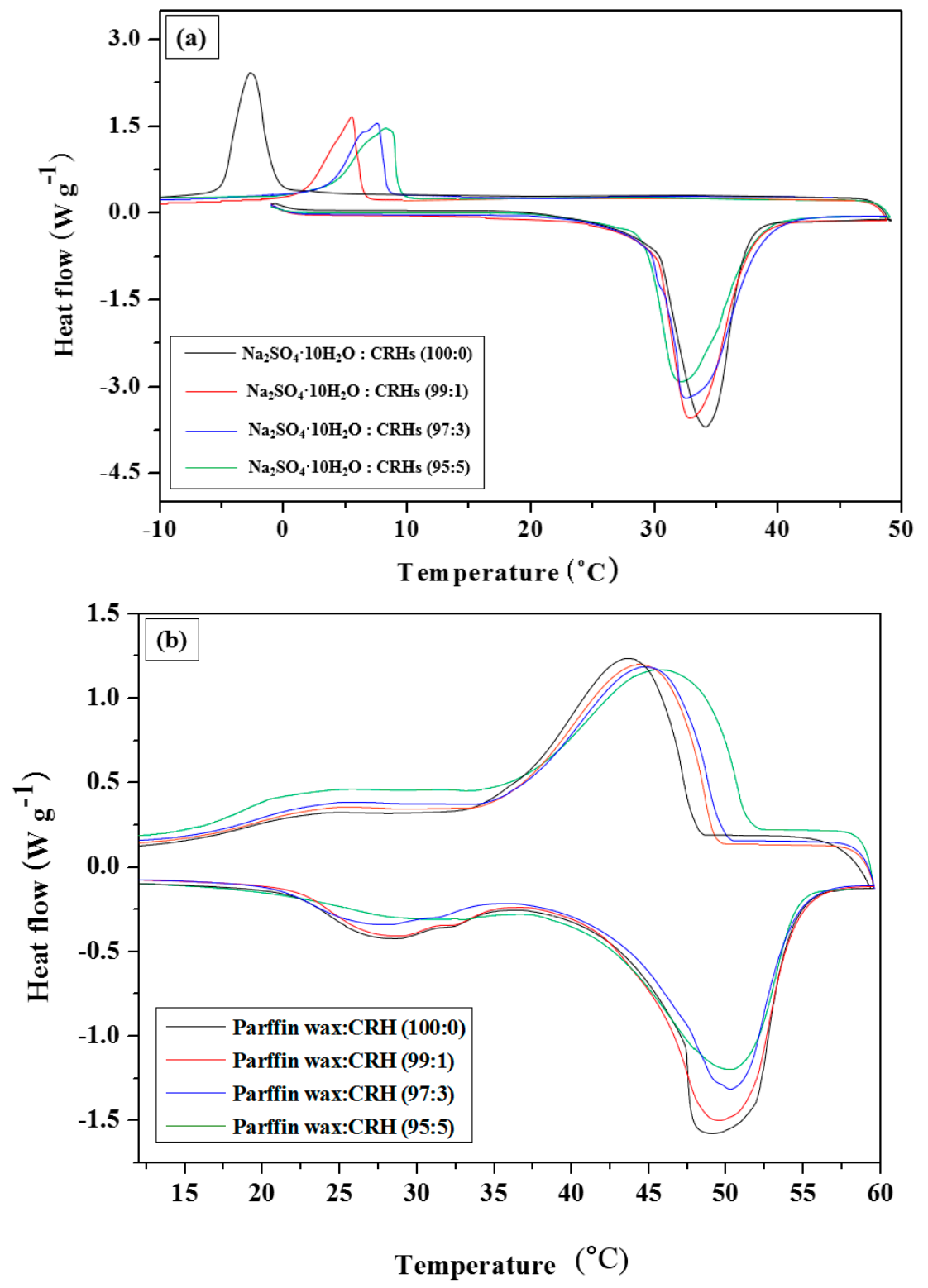

Figure 5. Differential scanning calorimetry (DSC) analysis of (a) $\mathrm{Na}_{2} \mathrm{SO}_{4} \cdot 10 \mathrm{H}_{2} \mathrm{O}$ and (b) paraffin wax according to wt. \% of CRHs. 
Table 3. Latent heat changes of phase change materials (PCMs) according to wt. \% of CRHs.

\begin{tabular}{ccccc}
\hline PCM & \multicolumn{4}{c}{ PCM:CRH wt. $\%$} \\
\hline $\mathrm{Na}_{2} \mathrm{SO}_{4} \cdot 10 \mathrm{H}_{2} \mathrm{O}: \mathrm{CRHs}$ & $100: 0$ & $99: 1$ & $97: 3$ & $95: 5$ \\
Latent heat $\left(\mathrm{kJ} \mathrm{kg}^{-1}\right)$ & $216.13 \pm 2.70$ & $201.62 \pm 1.03$ & $192.45 \pm 1.78$ & $185.28 \pm 2.01$ \\
Paraffin wax:CRHs & $100: 0$ & $99: 1$ & $97: 3$ & $95: 5$ \\
Latent heat $\left(\mathrm{kJ} \mathrm{kg}^{-1}\right)$ & $220.45 \pm 1.62$ & $208.23 \pm 2.01$ & $194.55 \pm 2.45$ & $188.09 \pm 1.47$ \\
\hline
\end{tabular}

3.3. Influence of $\mathrm{Na}_{2} \mathrm{SO}_{4} \cdot 10 \mathrm{H}_{2} \mathrm{O} / \mathrm{CRH}$ in the WPC on the Roof-Surface and Indoor Temperature of the Cool Roof Miniature Model

Figure 6 illustrates the effect of $\mathrm{Na}_{2} \mathrm{SO}_{4} \cdot 10 \mathrm{H}_{2} \mathrm{O} / \mathrm{CRHs}$ using the different fixed temperatures, on the roof-surface and the indoor temperatures. As depicted in Figure $6 a, b$, the surface temperature of the roofs with no PCM increased more steeply than those of the roofs with only $\mathrm{Na}_{2} \mathrm{SO}_{4} \cdot 10 \mathrm{H}_{2} \mathrm{O}$ or $\mathrm{Na}_{2} \mathrm{SO}_{4} \cdot 10 \mathrm{H}_{2} \mathrm{O} / \mathrm{CRH}$. These temperatures in Figure $6 \mathrm{a}$, b were maintained to be steady at approximately $59^{\circ} \mathrm{C}$ and $70{ }^{\circ} \mathrm{C}$, respectively. The temperatures of the indoor temperature with no PCM increased to $29{ }^{\circ} \mathrm{C}$. Concurrently, the roof temperature of the $\mathrm{Na}_{2} \mathrm{SO}_{4} \cdot 10 \mathrm{H}_{2} \mathrm{O}$-containing CRHs showed a lower increase than that for roof with only $\mathrm{Na}_{2} \mathrm{SO}_{4} \cdot 10 \mathrm{H}_{2} \mathrm{O}$. Indeed, as the $\mathrm{CRH}$ content increased, the roof-surface temperature increased at a slower pace and resulted in a lower overall temperature, compared to the roof with no PCM, and the indoor temperature showed a decreasing trend. These results are due to a faster roof heat absorption through the improved thermal conductivity of CRHs; this led to a faster melting of $\mathrm{Na}_{2} \mathrm{SO}_{4} \cdot 10 \mathrm{H}_{2} \mathrm{O}$. However, at the fixed temperature of 40 to $42{ }^{\circ} \mathrm{C}$ in Figure $6 \mathrm{c}$, all roof surface temperatures reached approximately $80^{\circ} \mathrm{C}$. Indeed, after $1000 \mathrm{~s}$ of artificial temperature measurements at the fixed temperature of $40 \sim 42{ }^{\circ} \mathrm{C}$, the surface temperature of the roof with $\mathrm{Na}_{2} \mathrm{SO}_{4} \cdot \mathrm{H}_{2} \mathrm{O}$ comprising $5 \mathrm{wt}$. \% CRHs was observed to have only a slight difference of approximately $1{ }^{\circ} \mathrm{C}$, compared to the roof without $\mathrm{Na}_{2} \mathrm{SO}_{4} \cdot 10 \mathrm{H}_{2} \mathrm{O}$. This is due to it being out of range of the $\mathrm{Na}_{2} \mathrm{SO}_{4} \cdot 10 \mathrm{H}_{2} \mathrm{O}$ latent heat (see Figure $5 \mathrm{a}$ ). Therefore, it is evident that there was no effect on the roof-surface temperature regardless of whether or not $\mathrm{Na}_{2} \mathrm{SO}_{4} \cdot 10 \mathrm{H}_{2} \mathrm{O}$ or $\mathrm{Na}_{2} \mathrm{SO}_{4} \cdot 10 \mathrm{H}_{2} \mathrm{O}$ with CRHs were used at the fixed temperature of 40 to $42{ }^{\circ} \mathrm{C}$; however, the indoor temperatures were observed to keep lower for roofs containing $\mathrm{Na}_{2} \mathrm{SO}_{4} \cdot 10 \mathrm{H}_{2} \mathrm{O}$ or $\mathrm{Na}_{2} \mathrm{SO}_{4} \cdot 10 \mathrm{H}_{2} \mathrm{O}$ with CRHs than those of roof without PCM.

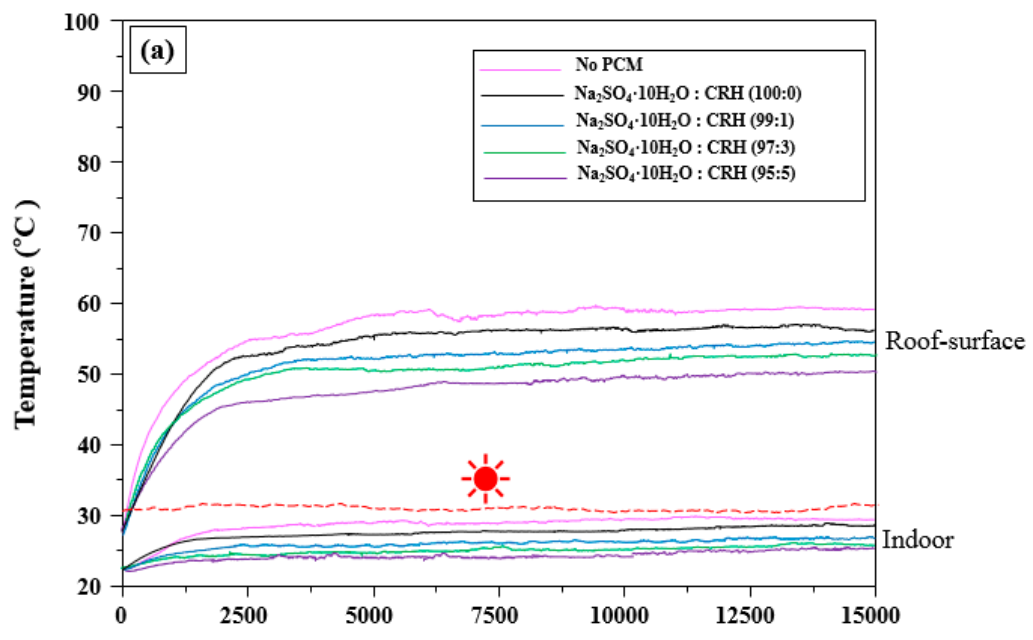

Figure 6. Cont. 

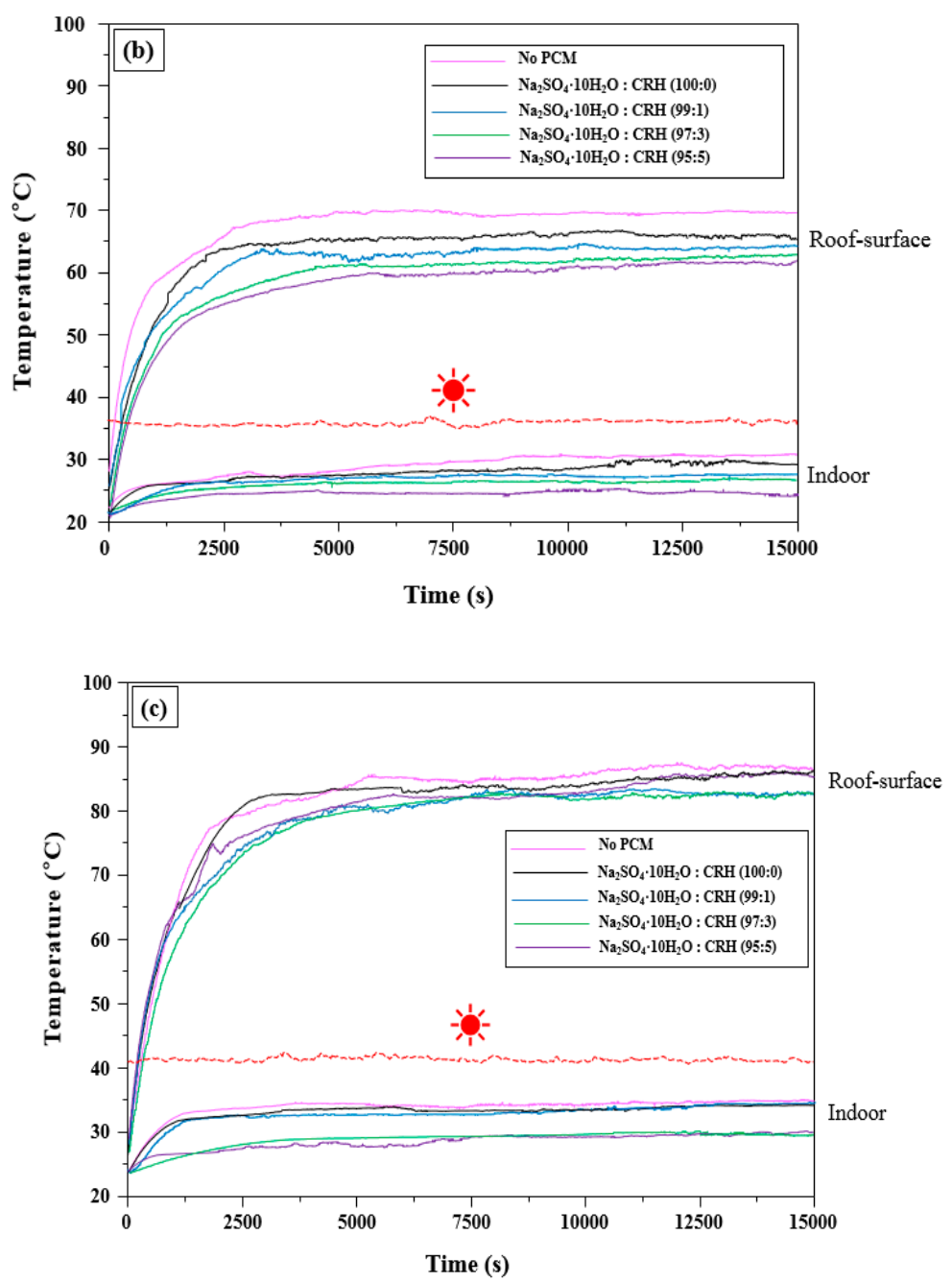

Figure 6. Time-temperature graphs for the temperature at the surface of the roof and the lower part temperatures of a roof containing $\mathrm{Na}_{2} \mathrm{SO}_{4} \cdot \mathrm{H}_{2} \mathrm{O} / \mathrm{CRH}$ s using a fixed heat source (溶- depicts the fixed temperature): (a) 30 to $32{ }^{\circ} \mathrm{C}$, (b) 35 to $37^{\circ} \mathrm{C}$, and (c) 40 to $42{ }^{\circ} \mathrm{C}$.

3.4. Influence of Parffin Wax/CRH in the WPC on the Roof-Surface and Indoor Temperature of the Cool Roof Miniature Model

Figure 6 illustrates the effects of paraffin wax with CRHs using a fixed heat source $\left(30\right.$ to $32{ }^{\circ} \mathrm{C}$, 35 to $37^{\circ} \mathrm{C}$, and 40 to $42{ }^{\circ} \mathrm{C}$ ) on the temperatures of the roof-surface and the indoor temperature of the roof. The roof-surface and indoor temperatures containing paraffin wax with CRHs were observed to increase less than those of roofs without PCM. Additionally, as the CRH content increased, roof-surface temperatures increased at a slower pace, and the indoor temperatures were maintained to be lower; this was similar to the temperatures of the roof surface and the indoor containing $\mathrm{Na}_{2} \mathrm{SO}_{4} \cdot 10 \mathrm{H}_{2} \mathrm{O}$ with CRHs. In the cases of the fixed temperatures of 30 to $32{ }^{\circ} \mathrm{C}$ and 35 to $37{ }^{\circ} \mathrm{C}$, when compared to roofs without PCM, the roof-surface temperatures with paraffin wax with CRHs and without PCMs showed a maximum difference of approximately $7^{\circ} \mathrm{C}$ and $11^{\circ} \mathrm{C}$, respectively; further, the indoor temperatures exhibited a maximum difference approximately $4{ }^{\circ} \mathrm{C}$ and $6{ }^{\circ} \mathrm{C}$, respectively. However, at the fixed temperature of 40 to $42{ }^{\circ} \mathrm{C}$, as the $\mathrm{CRH}$ content increased, the roof-surface temperatures decreased. In particular, the surface temperature of roofs containing paraffin wax with $5 \mathrm{wt}$. \% CRHs reduced to $74.6^{\circ} \mathrm{C}$; further, the indoor temperature also decreased to $26.4^{\circ} \mathrm{C}$, even though the roof-surface and indoor temperatures without PCM reached $86^{\circ} \mathrm{C}$ and $35.5^{\circ} \mathrm{C}$, respectively. Therefore, it has been concluded that selection of PCMs with higher $\mathrm{T}_{\mathrm{m}}$ than the summer temperatures of each location can significantly influence the reduction of roof-surface temperatures and indoor temperature in buildings. 

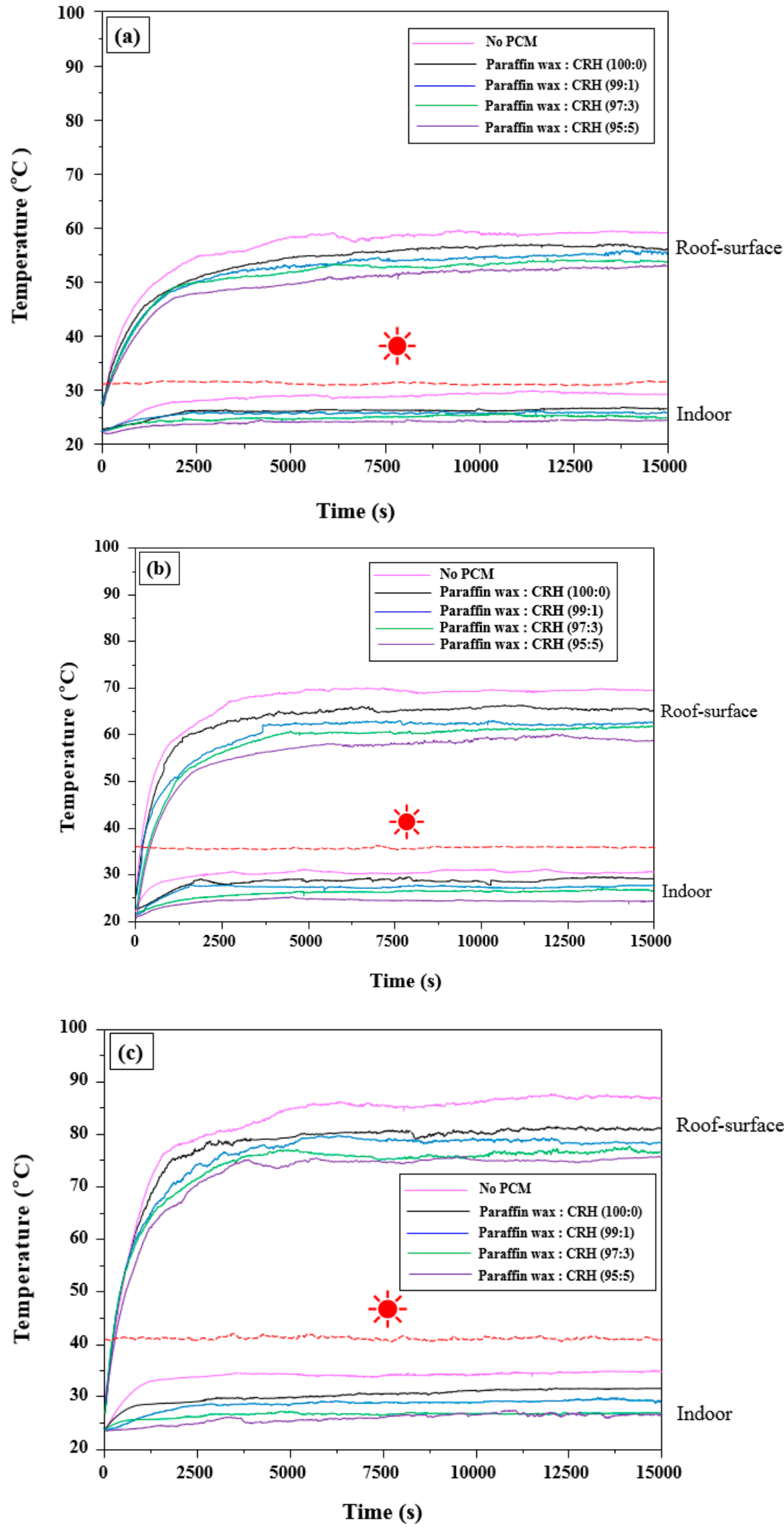

Figure 6. Time-temperature graphs for surface and lower part temperatures of roofs containing paraffin

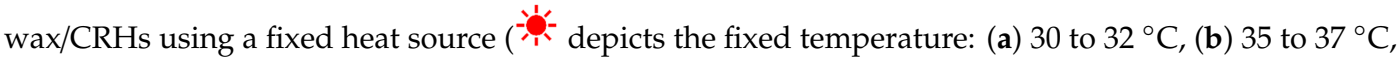
and (c) 40 to $42^{\circ} \mathrm{C}$ ). 


\section{Conclusions}

This study aimed to obtain lower roof-surface and indoor temperatures through the fast heat absorption of PCMs in WPC of roof finishing materials; this was achieved by improving the thermal conductivity of PCMs through CRHs. Under the fixed temperature of 30 to $32^{\circ} \mathrm{C}$ and 35 to $37^{\circ} \mathrm{C}$, the surface temperature of the roofs containing $\mathrm{Na}_{2} \mathrm{SO}_{4} \cdot 10 \mathrm{H}_{2} \mathrm{O}$ and paraffin wax with CRHs increased at a slower rate than those of the roofs without PCMs. The indoor temperatures of the roofs containing $\mathrm{Na}_{2} \mathrm{SO}_{4} \cdot 10 \mathrm{H}_{2} \mathrm{O}$ and paraffin wax with $\mathrm{CRHs}$ were also maintained to be lower than those of the roofs without PCMs. Additionally, as the CRH content in the PCM increased, the rate of increase of the roof-surface and indoor temperatures also decreased because of a faster heat absorption of the roof surfaces by PCMs due to the improved thermal conductivity through CRHs. However, under a fixed temperature of 40 to $42{ }^{\circ} \mathrm{C}$, the surface temperature of the roof containing $\mathrm{Na}_{2} \mathrm{SO}_{4} \cdot 10 \mathrm{H}_{2} \mathrm{O}$ with 5 wt. \% CRHs increased to approximately $80^{\circ} \mathrm{C}$, which was similar to that of the roof without PCM. This was due to being out of range of the latent heat of $\mathrm{Na}_{2} \mathrm{SO}_{4} \cdot 10 \mathrm{H}_{2} \mathrm{O}$; however, the indoor temperatures containing $\mathrm{Na}_{2} \mathrm{SO}_{4} \cdot 10 \mathrm{H}_{2} \mathrm{O}$ with $\mathrm{CRH}$ were still maintained to be lower than those of the roofs without PCMs. In the case of paraffin wax with Tm of $48^{\circ} \mathrm{C}$ and under the fixed temperature of 40 to $42{ }^{\circ} \mathrm{C}$, the $\mathrm{CRH}$ content was observed to increase, and the roof-surface temperatures decreased. In particular, when compared to roofs without PCMs, the surface temperature of roof containing paraffin wax with $5 \mathrm{wt}$. \% CRHs reduced to $74.6{ }^{\circ} \mathrm{C}$ of a maximum difference of approximately $11{ }^{\circ} \mathrm{C}$ and its indoor temperature was also lowered to $26.4^{\circ} \mathrm{C}$. In this study, the improvement of the thermal conductivity of PCM by the addition of the CRHs and a suitable PCM selection in each location can result in the reduction of the roof-surface and indoor temperatures.

Author Contributions: Conceptualization H.K.S.; Experimental work, H.K.S., Y.-S.K., and M.P.; formal analysis, H.K.S. and L.K.K.; resources, H.K.S., M.P., and H.G.K.; data curation, H.K.S., Y.-S.K., and M.P.; writing-original draft preparation, H.K.S.; writing-review and editing, H.K.S.; supervision, H.K.S. and H.G.K.; project administration, H.K.S. and H.G.K. All authors have read and agreed to the published version of the manuscript.

Funding: This research was supported by Basic Science Research Program through the National Research Foundation of Korea (NRF) funded by the Ministry of Education (No. 2016R1A6A1A03012069). This research was also supported by Traditional Culture Convergence Research Program through the National Research Foundation of Korea (NRF) funded by the Ministry of Science, ICT, and Future Planning (2018M3C1B5052283).

Conflicts of Interest: The authors declare no conflict of interest.

\section{References}

1. Jayasinghe, M.T.R.; Attalage, R.A.; Jayawardena, A.I. Roof orientation, roofing materials and roof surface color: their influence on indoor thermal comfort in warm humid climates. Energy Sustain. Dev. 2003, 7, 16-27. [CrossRef]

2. Ozel, M. Effect of indoor design temperature on the heating and cooling transmission loads. J. Build. Eng. 2016, 7, 46-52. [CrossRef]

3. Arumugam, R.S.; Garg, V.; Ram, V.V.; Bhatia, A. Optimizing roof insulation for roofs with high albedo coating and radiant barriers in India. J. Build. Eng. 2015, 2, 52-58. [CrossRef]

4. Karam, M.A.; Mazran, I.; Abdul, M.A.R. A review of the potential of attic ventilation by passive and active turbine ventilators in tropical Malaysia. Sustain. Cities Soc. 2014, 10, 232-240.

5. Anna, L.P. Thermal-energy analysis of roof cool clay tiles for application in historic buildings and cities. Sustain. Cities Soc. 2015, 19, 271-280.

6. Latha, P.K.; Darshana, Y.; Venugopal, V. Role of building material in thermal comfort in tropical climates - A review. J. Build. Eng. 2015, 3, 104-113. [CrossRef]

7. Fahmy, M.; Sharples, S. On the development of an urban passive thermal comfort system in Cario. Build. Environ. 2009, 44, 1907-1916.

8. Giridharan, R.; Ganesan, S.; Lau, S. Daytime urban heat island effect in high-rise and high-density residential developments in Hong Kong. Energy Build. 2004, 36, 525-534. [CrossRef]

9. Giridharan, R.; Lau, S.; Ganesan, S.; Givoni, B. Urban design factors influencing heat island intensity in high-rise high-density environments of Hong Kong. Build. Environ. 2007, 42, 3669-3684. [CrossRef] 
10. Giridharan, R.; Lau, S.; Ganesan, S.; Givoni, B. Lowering the outdoor temperature in high-rise high-density residential developments of coastal Hong Kong: The vegetation influence. Build. Environ. 2008, 43, 1583-1595. [CrossRef]

11. Ibáñez, M.; Lazaro, A.; Zalba, B.; Cabeza, L.F. An approach to the simulation of PCMs in building applications using TRNSYS. Appl. Therm. Eng. 2005, 25, 1796-1807. [CrossRef]

12. Cabeza, L.F.; de Gracia, A. Thermal energy storage (TES) systems for cooling in residential buildings. In Advances in Thermal Energy Storage Systems; Cabeza, L.F., Ed.; Elsevier: Cambridge, UK, 2015; pp. 549-572.

13. Tabares-Velasco, P.C.; Christensen, C.; Bianchi, M. Verification and validation of EnergyPlus phase change material model for opaque wall assemblies. Build. Environ. 2012, 54, 186-196. [CrossRef]

14. Kuznik, F.; Virgone, J.; Johannes, K. Development and validation of a new TRNSYS type for the simulation of external building walls containing PCM. Energy Build. 2010, 42, 1004-1009. [CrossRef]

15. Kheradmand, M.; Azenha, M.; De Aguiar, J.L.B.; Krakowiak, K. Thermal behavior of cement based plastering mortar containing hybrid microencapsulated phase change materials. Energy Build. 2014, 84, 526-536. [CrossRef]

16. Shin, H.K.; Park, M.; Kim, H.Y.; Park, S.-J. Thermal property and latent heat energy storage behavior of sodium acetate trihydrate composites containing expanded graphite and carboxymethyl cellulose for phase change materials. Appl. Therm. Eng. 2015, 75, 978-983. [CrossRef]

17. Shin, H.K.; Rhee, K.-Y.; Park, S.-J. Effects of exfoliated graphite on the thermal properties of erythritol-based composites used as phase-change materials. Compos. Part B Eng. 2016, 96, 350-353. [CrossRef]

18. Kim, H.G.; Kim, Y.-S.; Kwac, L.K.; Shin, H.J.; Lee, S.O.; Lee, U.S.; Shin, H.K. Latent Heat Storage and Thermal Efficacy of Carboxymethyl Cellulose Carbon Foams Containing Ag, Al, Carbon Nanotubes, and Graphene in a Phase Change Material. Nanomaterials 2019, 9, 158. [CrossRef]

19. Haillot, D.; Bauer, T.; Tamme, R. Thermal analysis of phase change materials in the temperature range 120-150 ${ }^{\circ} \mathrm{C}$. Themochim. Acta 2011, 513, 49-59. [CrossRef]

20. Nomura, T.; Okinaka, N.; Akiyama, T. Waste heat transportation system, using phase change material (PCM) from steelworks to chemical plant. Resour. Conserv. Recycl. 2010, 54, 1000-1006. [CrossRef]

21. Yang, Y.K.; Kang, I.S.; Chung, M.H.; Kim, S.; Park, J.C. Effect of PCM cool roof system on the reduction in urban heat island phenomenon. Build. Environ. 2017, 122, 411-421. [CrossRef]

22. Li, N.; Zheng, Y.; Liu, C.; Wu, G. Numerical analysis on thermal performance of roof contained PCM of a single residential building. Energy Convers. Manag. 2015, 100, 147-156. [CrossRef]

23. Jayalath, A.; Aye, L.; Mendis, P.; Ngo, T. Effects of phase change material roof layers on thermal performance of a residential building in Melbourne and Sydney. Energy Build. 2016, 121, 152-158. [CrossRef]

24. Saffari, M.; de Gracia, A.; Ushak, S.; Cabeza, L.F. Passive cooling of buildings with phase change materials using whole building energy simulation tools: A review. Renew. Sust. Energ. Rev. 2017, 80, 1239-1255. [CrossRef]

25. Costanzo, V.; Evola, G.; Marletta, L.; Nocera, F. The effectiveness of phase change materials in relation to summer thermal comfort in air-conditioned office buildings. Build. Simul. 2018, 11, 1145-1161. [CrossRef]

26. Wang, C.; Feng, L.; Li, W.; Zheng, J.; Tian, W.; Li, X. Shape-stabilized phase change materials based on polyethylene glycol/porous carbon composite: The influence of the pore structure of the carbon materials. Sol. Energy Mater. Sol. Cells 2012, 105, 21-26. [CrossRef]

27. Wang, L.; Metcalf, S.; Critoph, R.E.; Thorpe, R.; Tamainot-Telto, Z. Thermal conductivity and permeability of consolidated expanded natural graphite treated with sulphuric acid. Carbon 2011, 49, 4812-4819. [CrossRef]

28. Marín, J.M.; Zalba, B.; Cabeza, L.F.; Mehling, H. Improvement of a thermal energy storage using plates with paraffin-graphite composite. Int. J. Heat Mass Transf. 2005, 48, 2561-2570. [CrossRef]

29. Wu, H.; Lu, C.; Zhang, W.; Zhang, X. Preparation of low-density polyethylene/low-temperature expandable graphite composites with high thermal conductivity by an in situ expansion melt blending process. Mater. Des. 2013, 52, 621-629. [CrossRef]

30. Chen, B.; Han, M.; Zhang, B.; Ouyang, G.; Shafei, B.; Wang, X.; Hu, S. Efficient Solar-to-Thermal Energy Conversion and Storage with High-Thermal-Conductivity and Form-Stabilized Phase Change Composite Based on Wood-Derived Scaffolds. Energies 2019, 12, 1283. [CrossRef]

31. Zhang, B.; Tian, Y.; Jin, X.; Lo, Y.T.; Cui, H. Thermal and Mechanical Properties of Expanded Graphite/Paraffin Gypsum-Based Composite Material Reinforced by Carbon Fiber. Materials 2018, 11, 2205. [CrossRef] 
32. Zhang, X.; Wen, R.; Huang, Z.; Tang, C.; Huang, Y.; Min, X.; Fang, M.; Wu, X.; Min, X.; Xu, Y. Enhancement of thermal conductivity by the introduction of carbon nanotubes as a filler in paraffin/expanded perlite form-stable phase-change materials. Energy Build. 2017, 149, 463-470. [CrossRef]

33. Agrawal, R.; Hanna, J.; Gunduz, I.E.; Luhrs, C.C. Epoxy-PCM Composites with Nanocarbons or Multidimensional Boron Nitride as Heat Flow Enhancers. Molecules 2019, 24, 1883. [CrossRef] [PubMed]

34. Qu, Y.; Wang, S.; Tian, Y.; Zhou, D. Comprehensive evaluation of Paraffin-HDPE shape stabilized PCM with hybrid carbon nano-additives. Appl. Therm. Eng. 2019, 163, 114404. [CrossRef]

35. Vivekananthan, M.; Amirtham, V.A.; Mayilvelnathan, V.; Arasu, A.V. Characterisation and thermophysical properties of graphene nanoparticles dispersed erythritol PCM for medium temperature thermal energy storage applications. Thermochim. Acta 2019, 676, 94-103. [CrossRef]

36. Liu, Z.; Chen, Z.; Yu, F. Enhanced thermal conductivity of microencapsulated phase change materials based on graphene oxide and carbon nanotube hybrid filler. Sol. Energy Mater. Sol. Cells 2019, 192, 72-80. [CrossRef]

Sample Availability: Samples of the compounds are not available from the authors.

(C) 2020 by the authors. Licensee MDPI, Basel, Switzerland. This article is an open access article distributed under the terms and conditions of the Creative Commons Attribution (CC BY) license (http://creativecommons.org/licenses/by/4.0/). 